$\Phi=5$

\title{
Lived Experiences of Women Who Underwent Induced Abortion: A qualitative study of Rakai District, Uganda
}

\author{
Nalubega Joy Margaret ${ }^{1}$, Omona Kizito $[\mathrm{PhD}]^{1^{*}}$ \\ ${ }^{1}$ Lecturers, Uganda Martyrs University, Faculty of Health Sciences \\ *Corresponding author: E-mail: komona@umu.ac.ug
}

\begin{abstract}
Background: Induced abortion is one where products of conception are expelled before 28 weeks of gestation. The process can be safe or unsafe. Safe termination of pregnancy is performed by skilled persons using appropriate tools whereas unsafe induced abortion is performed either by persons without the necessary skills or in an environment without the minimum medical standards, or both.

Objectives: To explore the lived experiences of women who had induced abortion in Rakai District

Methodology: Phenomenological qualitative design was used. Study population was women who underwent induced abortion. 25 women who had induced abortions in past 1-3years were interviewed. Data was collected by in-depth interviews, tape recorded; transcribed verbatim and written in note book.

Results: Lived experiences included denial, shame, confusion, fear, anger, anxiety, depression and uncertainty. Participants reported use of local herbs like "ekiwoko" and "majaani", "etwaata", "kisuula" and roots of sugar canes, among others, to induce abortion. The processes were mostly traditional, associated with: severe pain, heavy bleeding, and so on. They were life-threatening and horrible. Shortand long-term lived experiences included secondary barrenness, depression, crying-in-privacy and regrets, among others.

Conclusion: Health workers and women in child-bearing age need to work together to discuss how to control unplanned pregnancies.
\end{abstract}

Keywords: Lived Experiences; Induced Abortion; Quality of Care.

\section{Introduction}

\subsection{Background of the study}

The term "abortion" is derived from the Latin word aboriri, which means "to perish" (Henry, 1992). It entails both induced and spontaneous abortions. Induced abortion, which is the subject of this study, is a universal phenomenon occurring at all levels of societies where the products of conception are expelled before 28 weeks of gestation. The abortionists consist mainly of health workers' facilities, hospitals, health centers, dispensaries, ordinary bedrooms and occasionally in a simple room. Induced abortion is either safe abortion or unsafe abortion (Neema, 2016). Safe termination of pregnancy is performed by skilled persons using appropriate tools in a sanitary environment whereas unsafe induced abortion is a performed either by persons without the necessary skills or in an environment without the minimum medical standards, or both (WHO, 2011)

The World Health Organization (WHO, 2006) estimates that 46 million abortions are performed each year, 20 million of which occur in countries where abortion is punishable by law. One in three women will at least have an abortion in their lifetime (Henshaw, et al., 2008). Worldwide; women who seek to induce an abortion have different demographic characteristics. Levels of unintended pregnancies and unsafe abortions are higher among young unmarried women below twenty-five years of age in Africa than in any other regions of the world (Shah, et al., 2009).

It's estimated that one in three women will have an abortion during their lifetime (Henshaw, et al., 2008). Over 42 million abortions are estimated to be performed annually worldwide, and of which those carried out under safe conditions are 22 million. Worldwide, it's estimated that 21.9 million unsafe abortions are performed every year (WHO, 2011). Majority of the unsafe abortions are induced, where the women's lives are put at very serious risks during the procedures and the overall outcomes on their lifetime experiences is undesirable (Singh, Wulf, Hussain, Bankole, Sedgh, 2009). Of these unsafe abortions, 97\% occur in low income countries. Out of these, 44\% are recorded in Africa (Rasch, 2011).

Induced abortions are performed globally (Biney, 2011). In Uganda, however, induced abortion is illegal unless carried out on medical grounds. The Ministry of Health (MOH) estimates that maternal mortality due to abortion related causes was $26 \%$ in 2011 (MOH, 2012), a rate which is considerably higher than that reported in the Eastern African sub-region (13\%).

The reason for performing induced abortion varies from health-related issues to cultural norms and is subjective to the victims. These include, among others: rape, defilement, poverty, and failure to use contraception (Biddlecom, et al., 2008). Some perform it due to unintended pregnancies or as a birth control method (Bogart's \& Westoff, 2000). Some women use induced abortion as a tool to regulate menstruation, others to terminate teenage pregnancies, while to others do it with the desire to continue with education (Biney, 2011). However, the reasons given for having an induced abortion in surveys are often superficial. There may be many reasons why women induce abortion and the problem is persistently on the rise globally with undesirable outcomes (WHO, 2012). Studies by Upadhyay, 
Brown, Sokoloff, et al., (2012); Roberts, Silva, Xu (2010) done from a variety of countries (both developed and developing) such as India, Nepal and New Zealand indicate a range of perceptions toward induced abortion.

Two recent studies by public health researchers (Kassebaum, Bertozzi-Villa, Coggeshall, et al., 2014; Say, Chou, Gemmill, et al., 2014) indicated that globally by 2014 , induced abortions accounted for $8 \%-18 \%$ of maternal deaths. An earlier study by Singh (2006) indicated that millions more women suffer non-fatal health consequences of induced abortion every year.

The pre-abortion period is associated with mental health problems like negative attitudes towards abortion, lack of social support, conflict with an intimate partner. There is, thus, need for coping strategies to ensure good socio-cultural and psychological health outcomes following an abortion procedure (Alanson, 2007).

Keogh, Kimaro and Muganyizi (2015) indicated that in the East African region alone, an estimated 613,000 women were hospitalized due to induced abortion related complications (Singh, 2006). Keogh et al. (2015) further noted that today many more women suffer complications but do not access care. In Uganda, health indicators are still poor. The total fertility rate stands at 6.2 children per woman (UBOS, et al., 2012). The maternal mortality rate is 310 per 100,000 live births. Abortion related deaths contribute $26 \%$ to this maternal death (WHO, 2012).

Therefore, almost all countries have laws prohibiting the execution of an induced abortion unless when it's under the acceptable circumstances of the law. Likewise, Uganda has laws that prohibit and permit induced abortion under certain conditions. However, these laws and policies are not precise enough and they are always interpreted incoherently. This, then, brings a challenge of hardship to the women and the medical community to comprehend what is legally allowed (CRR, 2011). The result of this is refusal of the medical providers to perform or induce an abortion for fear of the consequences. This, then, calls for the use of unsafe abortion procedures.

Unwanted pregnancies are on the rise, with 1.4 million pregnancies occurring in Uganda (Khan, et al., 2008). This increasing numbers of unwanted pregnancies in Uganda play a very big role on the increasing numbers of unsafe abortions, which constitutes almost one third of maternal deaths with the country's young people (Singh, Prada, Mirembe \&Kiggundu, 2005; Nalwadda, et al., 2005). This has led to increased hard lived experiences that are experienced by the victims. This greatly raises the need for this study on the lived experiences of women who underwent induced abortion in Rakai District.

\subsection{Study area}

This research study was conducted in Rakai District. The district is located in the South-western central region of Uganda. Rakai District was selected because it was one of the places in Uganda which was hard hit by HIV/AIDS in the past years and known of promiscuous sexual activities where unwanted pregnancies are rampant.

\subsection{Secondary objective of the study}

To explore and describe the lived experiences of women who underwent induced abortion in Rakai district.

\subsection{Primary objectives of the study}

1) To explore the lived experiences of women who had had induced abortion in relation to learning about the aborted pregnancy in Rakai District_Uganda

2) To describe the lived experiences of the process of inducing abortion among women who underwent induced abortion in Rakai District_Uganda

3) To determine the short-term lived experiences after induced abortion among women who underwent induced abortion in Rakai District_Uganda

4) To explore the long-term lived experiences after induced abortion among women who underwent induced abortion in Rakai District _ Uganda

\section{Methodology}

\subsection{Research design}

A phenomenological approach of qualitative study design was used. This framework enables the understanding of human phenomena that occur in the world of life, also called the social world (Ndunyu, 2013).

\subsection{Study population}

The population of interest included women who lived in Rakai and who underwent induced abortion.

\subsection{Sample size estimation}

Finlay (2011) and Smith, Larkin and Flowers (2009) recommended that when utilizing the phenomenological methods of research, the sample size should range from 5 - 25 participants. This study considered a sample of 25 women who had had induced abortions in the past 1-3years.

\subsection{Sampling procedure}

Participants were selected purposively basing on the available records. In some instances, snowball sampling, if the participant knew of any other woman who had induced abortion, was used. The information from women who underwent induced abortion was obtained from health facilities within Rakai district. Snow ball sampling was considered to be more likely to capture women who had recent induced abortions and/or more complicated abortions, as these were remembered more by their acquaintances.

The advantage of this method is that it enabled the researchers to identify respondents of interest from people who are rich with particular information (Creswell, 2007). Still, this method enabled the researchers to obtain an in-depth understanding of the phenomena of interest. 
Participants were chosen specifically only when they met certain demographic and phenomenological criteria (Johnson, et al., 2008). For example, women below 18 years, who could not consent, were not included in the study.

\subsection{Inclusion and exclusion criteria}

The study included women who had told someone about their abortion and excluded women who kept abortion as a top secret. Women with unsuccessful induced abortions and women who died were excluded. Similarly, as the study would capture and recruit only women who did abort a pregnancy, women who tried but failed to abort a pregnancy were excluded.

\subsection{Study variables}

The dependent variables were; Unwanted pregnancies, Induced abortion, Positive and negative lived experiences of the process of inducing abortion. Others were Positive Short- and Long-Term lived experiences after the induced abortion, Negative Short- and Long-Term lived experiences after the induced abortion.

The independent variables were; Age, Religion, Marital status, Occupation, Level of education, Exposure to Family Planning information and Ever use of contraceptives. Others were; History of induced abortion, Reasons for induced abortion, Age at first sexual intercourse, Number of sexual partners and History of pregnancy.

\subsection{Data collection methods}

In-depth Interviews: The researcher collected data by conducting in-depth interviews of women who underwent an induced abortion and recorded their views in a note book. The use of in-depth interviews helped the researcher to ascertain the participants' views of the phenomenon, its description and to generate meaning from those who experienced it accordingly (Creswell, 2007).Interview was conducted until there were no new ideas generated or expressed by the participant; what is termed as 'a point of saturation or redundancy'.

Tape recording: During the interview, the researchers recorded all information appropriately using a tape recorder. This facilitated the capturing of every detail of information. It avoided omission of important information from the participants.

\subsection{Quality control}

A number of quality controls were taken care of. These included member checks, triangulation of methods and tape recording for future analysis.

\subsection{Data management and analysis}

The researchers transcribed verbatim by playing the audio recordings and writing in a note book what was recorded. After transcribing the recorded data, the researchers re-checked for accuracy if it was in line with the participants' narrations.

Data analysis in this study followed the steps adopted by researchers in the tradition of the social phenomenology of Alfred Schütz (cited in Carvalho, Merighi and Jesus 2010) which includes reading; detailed re-reading of each testimony to grasp the experience's global meaning; identification and later grouping of the significant aspects of testimonies to compose concrete categories. Objective syntheses of different meanings of actions that emerged from experiences were done.

The qualitative data from the interviews was analyzed by thematic content analysis. This is a research tool used to determine the presence of certain words or concepts within texts or sets of texts. Recording was integrally and literally transcribed into verbatim transcripts which were then analyzed to identify patterns and themes for thematic content analysis. The transcriptions were coded into manageable categories (words or themes with similar meanings or connotations).

\subsection{Ethical considerations}

Ethical considerations were taken care of, including ethical approval.

Informed consent was sought from the participants and confidentiality was guaranteed.

\section{Results}

\subsection{Characteristics of respondents}

Respondents were all females who had induced abortions in a period not exceeding three years at the time the study. They were from several religious backgrounds including Catholics, Muslims and born again, with majority being Catholics. The respondent's ages ranged between 19-34years. They were mostly semi-literate with many having completed only up to primary seven. Among the participants, only one had formal employment, one had semi-permanent employment, two were school drop-outs and others housewives or farmers. Only two participants were properly married whiles others were co-habiting or not married at all.

\subsection{Lived experiences of women who had had induced abortion in relation to learning about the aborted pregnancy}

The experiences were related to reasons for induced abortion. A number of themes were generated;

\section{Theme 1: Lack of commitment}

Some partners were in relationships just for leisure. They had no plans of extending the relationships. One lady indicated she was only comfortable with the man as long as she did not produce for him. She thus narrated,

Angela [Not real name]: "I thought it was stressful to tell my partner about this development. I didn't want to parent with him and I took our relationship just for companionship but not for a continuous obligation of a serious family". 


\section{Theme 2: Fear of rejection}

There were cases where participants would have loved to carry on the pregnancies but feared for the reaction of the conservative parents who were reasoning in terms of tribes.

Hajara [Not real name]: "my parents would abuse and kill me on hearing that I am pregnant because I am their first-born child and they have a lot of hope in me; so, I decided to induce the abortion"

Another respondent assured the researchers that she was sure her parents would not accept a man from another tribe and this was the reason for abortion. She explained,

Ruth [Not real name]: "My boyfriend was from another tribe and my parents would not have approved".

\section{Theme 3: Shame}

Another mother confessed that they had a mutual agreement with the husband not to produce any more children. She, however, had an extra marital affair with another man. She thus confessed,

Harriet [Not real name]: "I felt ashamed and I had nowhere to start. How could I tell my husband that I was pregnant, besides I was not sure whether my husband or the other man was the one responsible?"

There were several other confessions of not being ready and a feeling of being caught unaware. In this line, a certain woman confessed,

Harriet [Not real name]: "I am the first born at home; my parents had a lot of hope in me. How would they feel on learning that I was studying and had become pregnant?"

Florence [Not real name]: Another woman, Florence confessed ".... all I knew is where he was renting, I also didn't know the original home of my boy-friend only where he was renting".

\section{Theme 4: Unplanned pregnancy}

From another married woman,

Harriet [Not real name]: "The decision between delivering a baby and inducing the abortion was so difficult for me, because honestly, this pregnancy was unplanned and I was not even sure of the owner"

Irene [Not real name]: "Unfortunately, one time, my boyfriend, either intentionally or accidentally did not use any protection and I was in my unsafe days. Automatically I became pregnant."

Some unplanned pregnancies were really complex. A lady, who had not yet known her father, never wanted her kids to undergo the similar experience. Rather than giving birth to a kid whose father is not known, she would rather abort. She thus indicated,

Adrine [Not real name]: "I was not sure who my aborted child's father was. Still, I was not working, so I could not support myself just in case.I had not known my own father by that time (my mum was also a player somehow), and I wanted my child to know his or her dad"

\section{Theme 5: Peer influence}

The study found that women who consulted their friends were mostly those who ever had an abortion. Other women consulted their peers on account that they had enough experience in the use of local herbs; and also in part, because parents of the pregnant women would be so hostile and uncooperative. This left them with chance except to consult peers. A woman for instance noted that;

Florence [Not real name]: "I got a friend to whom I disclosed my problem and she reassured me that since am still young, I will get another pregnancy so I can induce the abortion, for she had done it before!"

Such assurance would serve only to encourage the woman to go ahead and abort.

\section{Theme 6: Relationship complexity}

The study further explored more reasons for inducing abortions. The study found that relationship complexities were some of the key factors precipitating induced abortions. A woman revealed that she was not sure of the father of her child.

Another woman said;

Mary [Not real name]: "Why I induced the abortion the first time at 22 years, I conceived and my husband seemed loving at first but later started denying ownership of the pregnancy!! I had a girl-friend who also fell in love relationship with my husband yet rumour was saying that she was HIV positive. So, I got annoyed and I started.......according to what the man had done to me, I decided to induce the abortion".

Phiona [Not real name]: "this man made me pregnant but I had no single drop of love for him."

Annet [Not real name]: "Towards the end of the fourth month, my boy-friend began behaving in a way that suggested he did not want my pregnancy"

At times, women were forced to abort as men denied responsibility for their pregnancies. This was revealed by one of the ladies, who said;

Hope [Not real name]: I introduced the subject of pregnancy to my beloved boyfriend. He certainly made it clear he did not want a child at that point. I felt like a dream.

Other respondents indicated;

Adrine [Not real name]: "I was upset by my boy-friend and I decided to go for abortion"

Barbra [Not real name]: "[...] He insulted me and beat me up day and night. I decided very penitently on abortion. I was raised in a two-parent family and felt most strongly that a baby deserves the love of both the mother and the father. I was not seeing this kind of life ahead of my unborn child". 
Another woman revealed how she was unfaithful and in the process got pregnant and she was not ready to be ashamed. She thus said, Racheal [Not real name]: "Unfortunately, I stepped aside of marriage and got a man who impregnated me and I feared how I would explain that pregnancy to my husband, so I go challenged and I decided to induce that abortion."

Another respondent revealed that by the time she got pregnant, she had multiple boyfriends and she could not hold any of them accountable with certainty, she thus said;

Grace [Not real name]: "I finally got pregnant, not even knowing whom to hold accountable for my pregnancy since I had multiple boyfriends".

From the above, it can be inferred that the decision to terminate the pregnancy was a result of anger and the need to punish the cheating husband or boy-friend. On the other hand, the cheating woman could not help being exposed, all of which depict relationship complexities.

\section{Theme 7: Poverty}

In addition, the women were concerned about their welfare and the welfare of their babies. For instance, a certain woman, on becoming pregnant and while contemplating abortion had this to say;

Mary [Not real name]: "so I imagined if I deliver the baby, what I will use....like clothing....so I decided to in-

duce the abortion because the man kept denying the pregnancy many times and I was challenged".

The economic considerations were much pondering in the minds of women as seen above. More mothers also confessed to looking at the economic implications of the pregnancies they were carrying before finally deciding to terminate them. This was further aggravated by lack of support from the husband. Another respondent revealed that she did not want to lose newly acquired job. One of the respondents, a properly married born again, said;

Racheal [Not real name]: "My husband is not well off, our socio-economic status is poor; so this also greatly influenced my decision to induce that abortion. However, it was not in my plans of ever inducing an abortion in my life but I honestly had no alternative."

A young lady confessed,

Hajara [Not real name]: "The boy I (fellow student) denied ownership of my pregnancy and I had no means of survival."

Another respondent said,

Florence [Not real name]: "I had no financial support and where I was sleeping....!! But I tried to look for a job...in vain. So, I decided to induce the abortion."

Nambi [Not real name]: "Remember the boy-friend responsible for my pregnancy was not working, just a student like me. I did not even bother to tell him about the pregnancy. I chose to follow through with an abortion, sponsored by my Aunt".

From the above, the study shows that financial support was a key issue for the women who later aborted.

\section{Theme 8: Continuity of Schooling}

In addition, some women were concerned about their studies and had to weigh whether to forfeit the studies and carry the pregnancies or to abort and continue studying. One of the participants said,

Hajara [Not real name]: "I badly wanted to complete studies. I was studying in senior three going to senior four" another woman confessed "......this was because I wished to do my course in agriculture"

Hajara added that,

"I was forced to induce that abortion because I feared my parents and I was still studying so I didn't want to spoil my studying opportunities. And then the owner of the pregnancy had also denied ownership of my pregnancy so I decided to induce an abortion. Still I was not ready to deliver a baby at that time because I wanted to complete my studies and it came by mistake."

However, another respondent mentioned that her professional plan would have been destroyed.

Assumptah [Not real name]: "A baby would have broken up my profession plans......I couldn't bring a baby into this world without knowing how I was going to feed it, cloth it, love it and develop it."

From the above, it is clearly indicated that such women or girls were deeply concerned about their future academics and this influenced whether or not to carry the pregnancies.

\section{Theme 9: Feeling for the Baby}

The study further probed what women felt about the baby they were about to terminate. Surprisingly, many of the respondents did not seem to be concerned about what could happen to the babies. At the time, all their reflections were on the circumstances surrounding their pregnancy, for instance, financial support, studies, parent's reaction, saving their marriages, saving their jobs, their studies and their annoyance with the partners among others.

The thoughts about the baby were more or less secondary at the time of aborting. Such memories only came later especially the bad experiences on not being able to have children again, uterus being removed, seeing other people's children in the same age their aborted child would be, and others. 


\section{Theme 10: Excommunication from Family}

Most participants revealed that they suspected that their parents would react in a harsh way on hearing about their pregnancies. So, as an escape route, they decided to induce abortions. A young lady who was still under the care of her parents, on getting pregnant and aborting, had touching confessions when she said;

Flavia [Not real name]: "My daddy got to know about my induced abortion and he sent me away from home".

She also added,

Flavia: "Every person does not want to associate with me as before, even if I need anything, they just throw me away that am a spoilt child. My daddy drinks a lot and talks a lot of bad things about me in those different drinking places"

Another respondent revealed;

Florence [Not real name]: "When I told him about the pregnancy, he said he has nothing to do for me with the pregnancy. So, I thought of telling my parents and they wouldn't appreciate it so I decided to run away from home.... a bit fur from home."

Such scenarios as depicted in the above extract showed parents who are not realistic. Instead of helping the victimized daughter, they just threw them away. This serves to encourage other women to abort such that they avoid being noted as "spoilt" or "nuisance".

\section{Theme 11: Unwelcoming Religious Leaders}

In society, most people who are neglected would be expected to turn to the religious leaders. In Rakai, this was not the case. There are examples to illustrate this, where for instance, a woman was concerned, expressing that;

Flavia [Not real name]: ".....imagine seems, elders and the youth leader, got to know of my abortion because the few times I have gone to church after the abortion, they talked about it so much!!! So now I don't want to go to church ...I just pray from here."

From the above, instead of getting relief from the religious, this lady only found more grief and decided to keep home.

\section{Theme 12: Lack of direction}

Some respondents indicated that the acts of abortion were a result of lack of direction and poor upbringing. A lady confessed how she lived with an aunt who can best be described as a prostitute. Given this, she grew up with little regard for human life. She thus, lived not knowing that inducing abortion tantamounts to killing. She observed that;

Nambi [Not real name]: "[...] I did not know that abortion was really killing. To make matters worse, when I went to University I stayed with my aunt whose true fiancé I did not know since she had quite a number of them."

\subsection{Lived experiences of the process of inducing abortion among women who underwent induced abortion}

The study explored what exactly transpired in the process of inducing an abortion. Most mothers revealed that they were initially hesitant to visit professional medics and preferred to use local methods and local herbs. As the condition of the mother worsened, then they sought medical attention from qualified personnel. There is a range of methods and local herbs women confessed to have used, each with differing levels of success and risks as well. Two themes were generated;

\section{Theme 1: Health complications}

\section{Sub-theme A: Near death experience}

A respondent confessed that she nearly lost her life due to severe bleeding and severe pain. In another related case, a mother confessed that,

$$
\text { Patricia [Not real name]: "I lost a lot of blood, and the baby didn't come out well." }
$$

\section{Sub-theme B: Severe sickness}

Another respondent observed that local herbs failed. Later she got assistance from trained health workers. However, she got severely sick and weak.

Irene [Not real name]: "Too much bleeding, high fever, headeache, backache, loss of appetite followed immediately. I knew it was time to say my last prayers and leave my young children"

Some mothers made enough preparations for the process of inducing abortions, including making prior arrangements with the health workers. This somehow reduced the risk of severe sickness in the process. A mother narrated for instance,

Hajara [Not real name]: "On deciding to induce the abortion, I got close to some medic and agreed to assist me induce the abortion. We made an appointment and so we induced the abortion using tablets and then, he gave me tablets to help me heal properly. There were blood clots so I didn't see whether the baby was a boy or girl and I won't even want to know because I did not need that child at all."

From the above, it is indicated that the process of inducing abortions carried great risks with it, whether done by a medical professional or using local methods. In either case, mothers indicated that it was such a terrifying moment which they wished not ever to repeat or to be experienced by anyone. It, however, came out clearly that the process of inducing abortion ended up being referred to qualified personnel, or else, death would be more eminent. This could lead to the conclusion that the levels of risks are expected to reduce as more professionalism is available to handle the process of inducing an abortion.

One of the respondents, a young school-going lady who became pregnant, confessed;

Mary [Not real name]: "I used "ekiwoko" and "majaani" then she (my friend) advised me that after its been aborted, they can give etwaataobakisuula" 
Annet [Not real name]: "After a few hours, I saw heavy drops of blood coming out. Later on I felt as if I had labour pains. Then I fell unconscious. I woke up in a local clinic"

Another respondent narrated that,

Flavia [Not real name]: "I used roots of sugar canes, "ennanda” and "amajaani”...squeezed them together and I drunk them, then I aborted"

Following this, this respondent further said that it was a difficult moment, she stated, the abortion was followed by; Flavia: ".......severe pain with heavy bleeding yet I had nothing to eat or drink"

Angela [Not real name]: "After two days of taking the herbs, heavy drops of blood started coming out. I felt halfconscious for part of the day for about 3 hours".

Such was the situation where the mother was at great risk, no food and yet lost a lot of blood in the bleeding thereafter the abortion.

\section{Theme 2: Hostile Health Workers}

In relation to the above, another respondent noted that she used Herbs like ennanda, amajaani. The respondents also observed that many times the health workers were so hostile and abused them but finally were helpful. As a result of the abortion, a respondent noted that;

Harriet [Not real name]: "They washed inside my uterus and gave me several tablets.

From the above, it can be asserted that health workers were very vital much as they were most times hostile to the women intending to induce abortions

\subsection{Short-term lived experiences after the induced abortion}

The study found out that some women never regretted about the loss of the pregnancy in the first few moments because their decision to abort was influenced by emotions, frustration and stress from the men responsible. This reflects that women were driven by emotion rather than intuition to make their decisions.

\section{Theme 1a: Separations}

In some cases, abortions resulted in separation of the partners. This was evident when there was no consensus on whether or not to abort. A certain lady who was forced by the boy-friend to abort the pregnancy against her wish noted that,

Hope [Not real name]: "This time round we had to separate. I imagined, if this boy loved me why did he insist on abortion".

Others reported as follows;

Ruth [Not real name]: "We ended the relationship since the boyfriend got to know that my reason for aborting was that my family would not accept him" ...... can't imagine what he told his family because some how they got to know I was carrying his pregnancy and later no child was coming forth".

Angela [Not real name]: "[...] Remember, he got to know about my abortion and stayed with me any way since I was partly the source of his survival. Deep down, he was annoyed. When he got a chance of a good job, he poured all his bitterness to my ears. I cried and begged for forgiveness. He left me and married another woman and they are very rich now [...]"

\section{Theme 2a: Loss of Family Bonding}

Another immediate experience for women who induced abortions was that they were rejected by their families and felt they belonged nowhere. A young lady who was in her early 20's said,

Flavia [Not real name]: "My daddy got to know about my induced abortion and he sent me away from home...People just throw me away that am a spoilt child"

From the above, it is indicated that this lady and many others were discarded as wrong elements and instead of being given emotional support, they were driven into a sorrier state and feeling of isolation. This can even make other women who abort continue to hide and suffer silently as they are aware that society will only reject them and not respect their feelings and conditions.

\section{Theme 3a: Loss of studies}

For women who were in school, induced abortions were followed by loss studies. They, in most, cases failed to make it back to school, yet in the first place the reason to induce abortion was to ensure continuation of studying. A former school girl, a women in her late 20"s who dropped out of school after an abortion thus narrated,

Flavia [Not real name]: "...it was difficult for me to decide between delivering the baby and inducing the abortion but I decided in pain and induced it in order to go back to school but, unfortunately, I lost both the baby and studies."

\section{Theme 4a: Guilt and anger}

There were feelings of guilt and anger after the abortions. A lady confessed, Patricia [Not real name]: "I was schooling and my future was lost because of that induced abortion yet my parents had little money and I was greatly challenged. My life was too challenged after the abortion compared to the life I had before and even my parents were greatly annoyed with me." 
Hope [Not real name]: "I felt I had done a terrible thing to my family. I fill I am a bad girl in my family"

Women seemed to have developed a guilty conscience. In this case some mothers looked at themselves as murderers. A young lady who had failed to get pregnant for more than two years ever since she induced an abortion thought that God had punished her for being a murderer, she thus said,

Mary [Not real name]: "I see myself as a murderer, May be I am a murderer?"

Others added as;

Irene [Not real name]: "[...] I feel guilty up to now. I think I deserve to repent every day for what I did. I feel my children may hate me for killing one of them".

Angela [Not real name]: "I must even have been cursed..."

\section{Theme 5a: Fear of Being Revealed}

Here, mothers revealed that they lived in constant fear that, may be, one day someone will uncover their secrets and expose them. The study also found out that having an abortion made the mothers feel so ashamed of themselves, even when no one knew about it; others felt very shy thinking that someone might have known but opted to be silent.

From the above, we see double jeopardy; doing an abortion, leading to loss of both the baby and studies. Many of the women confessed that they could not continue schooling and imagined it would have been better if they carried their pregnancies and produced their children.

\section{Theme 6a: Regrets}

The study also found out that women who had induced abortion were regretting much, were in agony and felt they did something very bad. Many of them wished they could reverse their decision; however, it was too late. One respondent explained;

Mary [Not real name]: "I always regret.I am in agony and always in worries, wondering what I was up to when I induced abortion."

From the above, respondents indicated that they were not happy with their own decision to induce abortion.

\section{Theme 7a: Shifting blame to men}

Mothers blamed their situation on men; they felt men were very bad people who had forced them to act against their conscience and thus felt like not associating with men any more for relationship issues.

\section{Theme 8a: Stigma}

One lady who had been abandoned by the husband before aborting submitted that, Florence [Not real name]: "I hate my whole life, got worries, hate men and everybody."

Such expression above indicated an aggrieved woman, who hates herself and those around. Such emotions, if left unattended to, can lead to crime like homicide and breed other vices like abusing drugs, violence among others.

The religious people seemed not to have been supportive to help them out of their situation as one of the respondents indicated,

Flavia [Not real name]: "....the few times I have gone to church after the abortion, they talk about it so much!!!So now I don't want to go to church ...I just pray from here."

This indicates that she was disappointed by religious leaders pinning her instead of helping her out.

Abortion killed their confidence in public and thus they could not stand before any group of people publically, thinking someone could have known and decide to break their secret in public. As such, they avoided public places for as long as it was possible. This was a case of self-isolation. Some even feared their own relatives, thinking somehow they might have known what they did.

\section{Theme 9a: Sickness}

After the abortion process, women also revealed that their health was negatively affected. The effects ranged from physical to psychological and financial. Several ladies confessed how they became sick on and off, lost weight and got wasted, some had to run away from where they were known. One of the participants confessed that she bled to near death as the bleeding continued for more than a month after the induced abortion.

Phiona [Not real name]: "It was a terrible experience....Too much bleeding,anaemia, weight loss, sickness on and off and a string of other problems followed my unsafe abortion".

Other cases reported were that the mothers got wasted, had too much pain and bleeding. Other mothers became very weak and were always sick after the act of abortion. This was further aggravated by the use of local herbs, only to seek proper medical attention when their life was threatened to near death.

\section{Theme 10a: Loss of Uterus}

Two women confessed to have lost their uterus as they were removed later since they were rotting. "I almost lost my life due to a rotting uterus", said one of the respondents. A married woman who had got pregnant outside marriage and decided to induce an abortion also confessed that;
Rcheal [Not real name]: “...I got complications in the uterus. So, evacuation was done and I was given some drugs to help me squeeze out remains and blood.I bled, got severe abdominal pain, shame and fear amongst friends and also my husband. I almost lost my life. I almost lost my marriage"

\section{Theme 11a: Stress}

Initially, many of the mothers thought that once they abort, they would feel free. This was, however, not realized as many of them were instead more stressful afterwards. One of the participants noted that she was so stressed and anxious after the abortion. 


\section{Theme 12a: Weight Loss}

One of the respondents revealed;

Hajara [Not real name]: “....even my friends seemed so suspicious of the way I looked because I changed a lot -lost a lot of weight, darkened the skin and yetI was originally very brown; so, I think they knew about it even though they didn't tell me.I feel guilty that they were back-biting me, I suspected."

From the above, some women went through a period of uncertainty, not sure what people around them thought about them and how they would react.

On the other hand, some mothers were not bothered about their action of inducing an abortion. They were confident they did the right thing in the circumstances as they unfolded. One of the respondents, a woman in her 30's said,

Harriet [Not real name]: "...I don't feel much loss because the baby had no body parts, it was very young and only clots of blood were seen, so I don't really imagine how that baby was."

\section{Theme 13a: Detachment from Religion}

However, some women were concerned about their attachment with religion visa-vis their actions of inducing abortions. One of respondents commented;

Harriet[Not real name]: “.... but my religion as a catholic doesn't accept what I did and I really feel bad about it and I beg for forgiveness from my God because I honestly made a mistake and am guilty."

Annet [Not real name]: "I imagine if I died today, what will I answer God, that I killed an innocent baby, why?? God has all the rights to punish wrong doers like me. I even feel I am a misfit in church".

Barbra [Not real name]: "I wonder if God will ever forgive me for this".

Another respondent said,

Flavia [Not real name]: "My catholic faith doesn't accept what I did, so I fear going to church, I feel I sinned against my God."

Still another respondent confessed,

Patricia [Not real name]: "My church and religion is not in line with the decision I took to induce the abortion and even I feel unworthy staying among my people and community. I regret why I did this".

From the above, it can be inferred that reverence to religion was not enough to deter abortion; it was rather used for purposes of reflection, an unfortunate situation of acting before reflecting on the action.

\subsection{Long-term lived experiences after the induced abortion}

Mothers had experiences they underwent, even long after induced abortions. These were explored among the mothers in Rakai and the findings on these long-term experiences are narrated here below;

\section{Theme 1b: Feeling Sorry}

Even after a long period, some women who had aborted revealed that they still felt sorry about what they did. Such a feeling was associated with other problems of losing confidence, feeling less human and so forth. One lady clearly indicated that, Adrine [Not real name]: "I had an abortion when I was 21 years old. It was 10 weeks and I have been sorry about it ever since".

\section{Theme 2b: Repeated Habit}

There was a case of a respondent who revealed that for her, abortion had become part of her life. She, also, developed very bad drinking habits just to make sure she forgets the abortion experience, only to become pregnant again as a result of irresponsible drinking. For, she had multiple relationships; she revealed,

Nambi [Not real name]: "A year later, I developed despair that was only inflated by drinking alcohol. I again aborted twice, first at three months, then at 5 months in a space of two years".

\section{Theme 3b: Failure to Conceive}

The study found that some mothers had difficulty conceiving after induced abortion. Others failed completely to conceive again. This is a point when they became very disappointed of having wasted the "few" chances they had. This was followed by great agony, regret, confusion and self-blaming. A lady who aborted and later got a new husband, waiting for official marriage after conceiving, had tried for more than a year in vain. Her proposed formal marriage was becoming impossible due to failure to show the current boy-friend signs of being able to conceive. She, thus lamented,

Mary [Not real name]: "[...] I got married and got no child at all. I am worried most of the time. I think God had created only those two children in my womb whom I aborted!!!"

She then cried, and continued,

"I have deep thoughts about my aborted children. I cry in privacy and feel too bad up to today....... I am in grate agony, may be God had created only those two children for me, no baby, my marriage is going to break down because no baby"... she cried again.

Another respondent, a lady who was about 26 years old had to visibly regret as she narrated, Florence [Not real name]: “.... feel offended and depressed. When I see a lady breast feeding a baby, I greatly regret and imagine myself where my child would have reached, would be grown.I feel guilty of the child for 
whom I induced the abortion. Now I got a man and no child for a full year now!! So am confused. I want a baby but in vain.Sometimes I get great pain and I see as if my child is asking me "why did you do this mummy?"

Another lady added,

Irene [Not real name]: "No man can marry me since I can't produce. It is all rubbish and rubbish".

From the above, the study found out that women regretted their actions of inducing abortions, more especially when associated with failure to conceive again. Several other women had related confessions of doubting whether they will ever conceive.

\section{Theme 4b: Anxiety}

Some respondents had anxiety over a long period of time. One lady thus confessed,

Nambi [Not real name]: "I have tried anti-anxiety medications but my situation is not improving. There is a time when I attempted suicide" ...... I use alcohol to help me forget my dirty past, but whenever I am sober, thoughts of my unserious acts of abortion and the lives I denied a chance to live come up."

\section{Theme 5b: Guilty Feeling}

Another confession was from a perceiving, now barren woman, after induced abortion. She, while crying, revealed; Racheal [Not real name]: "I feel guilty as if I murdered someone. When I see children in the age of my induced abortion, I feel like I regret that I wish I hadn't induced that abortion, could be my child would have been alive like those children."

The interaction with this respondent in the study indicated that women regretted in the long run.

Racheal: "Talking about my induced abortion experience with you was not easy at first, but I again thought that you being a professional; may be of help to calm me down. And right now I feel relieved at least because of the guidance you have given me, because it has been really hurting me so much."

Another respondent indicated,

Hajara [Not real name]: "Today I feel relieved of the burden of the sin I did so I am a bit free because I have shared with you today. All along it has been between me and the medic who helped me to induce the abortion because I wouldn't even tell any friend about it."

Other respondents revealed grief in their hearts. For instance,

Grace [Not real name]: About a year later, my heart broke. I was so overcome with grief. How could I have taken the life of my unborn child?"

Clearly Grace was not happy with her decision to abort even after a year elapsed.

Barbra [Not real name]: "I, however, sometimes miss my baby since it would be playing around and asking me funny questions just like other babies. I really miss my baby. No matter how many children I will have, I will never forget this innocent child...I...destroyed"

\section{Theme 6b: Auditory hallucinations}

Another lady, confessed,

Hajara [Not real name]: "I am feeling guilty because I killed someone, it hurts me so much. I get voices asking me why did I induce that abortion, I would have left the baby to grow but I didn't need the baby and I already induced the abortion. I feel my baby would have grown by now. Anyway, I got confused of where I would have put the baby because the man had refused and my parent didn't know and I didn't want them to know at all."

\section{Theme 7b: Depression}

In the long-term, many of the mothers were not happy generally as they felt there was nothing that would be reversed. It was more depressing to imagine how old their children would be if they did not abort. From the above, mothers were not concerned about the actually abortion generally, but their key issue was failing to conceive thus leading them to reflect on what they had done. This could also point to the fact that, if the mothers had no challenges of conceiving, may be, they would not regret much.

Adrine [Not real name]: "This abortion has made me get depressions for years. Life has never been the same again".

\section{Theme 8b: Feeling a Society Misfit}

It was found that the society largely condemns abortion, so there is nothing much mothers who aborted would expect from the society in its current ideological setting. In this case, society includes the immediate family, the religious and friends. One of the respondents, a young lady in her early 20's who dropped out of secondary school after an induced abortion commented that,

Flavia [Not real name]: "I feel disgraced, segregated and hated. This should not have been the reaction of my immediate family. I advise girls to avoid admiring so much because I got to this situation because I wanted a lot of money. Also parents should be forgiving and understanding. They should guide us and not talk about us any how because we are still their children".

From the above confession, the study indicates that the society only blamed these women who induced abortions as means to deter other women from doing such. However, this act, created feelings of segregation, anger and lack of belonging to the women.

\section{Theme 9b: Self-condemnation}

Many of the women lived a life of being judged as wrong-doers, killers, murderers and sorts of blemish and judgment. From this, the study also explored what these women who had induced abortions were reflecting. Many of them had self-condemnation.

The respondents said, 
Patricia [Not real name]: "I advise girls to stay focused on their studies to avoid unwanted pregnancies".

Irene [Not real name]: "Use family planning and especially methods that prevent conceiving other than abortion".

\section{Discussions}

\subsection{Lived experiences of women who had had induced abortion in relation to learning about the aborted pregnancy}

Many of the respondents noted that pregnancy was the last thing they expected and lack of readiness pushed them to abort. This closely relates to what Welter (2015) noted citing that during their lifetime, many women will experience an unplanned and or unwanted pregnancy that invariably leads to a reproductive decision-making tree that may include abortion.

There were elements of unfaithfulness and unwanted pregnancies given the circumstances which forced mothers to abort against their will.

"I felt ashamed and I had nowhere to start, how I could tell my husband that I was pregnant, besides I was not sure whether my husband or the other man was responsible."

In relation to literature, Nader, Blandino and Maciel (2007) in their study in Brazil show that most women who had induced abortion had unplanned pregnancy. This same situation was seen to have happened to many women in Rakai. Sell et al, (2015) points out that fear of the reaction of parents or disappointing them was one of the driving issues inducing abortions, similar to what is seen in the cited case above. It thus follows that parents somehow played a role in influencing induced abortions indirectly.

This was clear indication that such a mother was not ready to carry on the pregnancy. Another expression where a mother confessed that,

"The decision between delivering a baby and inducing the abortion was so difficult for me, because honestly, this pregnancy was unplanned and I was not even sure of the owner".

All these indicate that many mothers on learning about their state of being pregnant were caught unaware. These findings are closely linked to previous research as documented by Major et al.(2000) who posited that a pre-abortion history of depression was strongly associated with post-abortion depression, low self-esteem and negative abortion outcomes.

The study found out that the most influential people in the decision of whether or not to abort were the peers. Parents were rather seen as being totally unaware of what their children (women who aborted) were going through. Grand-parents were also consulted basing on the account that they had experience in local herbs; and also partly because parents of the pregnant women would be so hostile and uncooperative.A woman for instance noted that,

"I got a friend to whom I disclosed my problem and she reassured me that since am still young, I will get another pregnancy so I can induce the abortion, for she had done it before!"

In the above case, the study shows how friends were very instrumental in influencing induced abortions.This finding is in support of what Appiah-Agyekum (2014) had earlier found out that $26.1 \%$ of the women or girls who induced abortions did so under direct experience and influence from peers - friends, course-mates, roommates.

\subsection{Lived experiences of the process of inducing abortion among women who underwent induced abortion}

Various local herbs were used, usually after consulting peers and old women. The most common herbs used were majaani (concentrated tea leaves mixed with hot water); "ekiwoko", roots of sugar canes, "etwaata" and "kisuula" and "ennanda".One lady confessed, "I used "ekiwoko" and "majaani" then she (my friend) advised me that after its been aborted, they can give "etwaata" or "kisuula". Another example found was,

"I used roots of sugar canes, "ennanda" and "amajaani"...squeezed them together and I drunk them, then I aborted".

There is also a linkage with literature where it is noted that using traditional methods of contraception were associated with a higher likelihood of a repeat of induced abortion (Maina, Mutua and Sidze (2015). Literature however does not explain how this happens.

Besides, abortion is still illegal in Uganda thus going to government facilities for such services would jeopardize the plans of the mother intending to induce the abortion. The only choice left was to resort to such unregulated, non-supervised and non-recommended means of inducing abortions. This finding agrees with Rasch, et al.(2014) who conclude that persistent use of these unregulated methods reflect the lack of easy alternative abortion options and signify the need for abortion policy which will pave the way for safer abortion services. The findings however contrast with what was found in Zanzibar where women terminated the pregnancy without physical sequel or need for PAC. It is possible that women who had a doctor terminate their pregnancies were given prophylactic antibiotics, thus reducing the risk of infection and potentially seeking formal PAC at the hospital (Norris, Harrington, Grossman et al., 2016)

\subsection{Short-term lived experiences after induced abortion}

The study revealed that some women never regretted about the loss the pregnancy in the first few moments as they had been frustrated by their spouses and felt were free from stress.

Another immediate experience is that the families of women rejected them and thus lost a sense of belonging. In one of the interactions, one participant said,

"My daddy got to know about my induced abortion and he sent me away from home. People just throw me away that I am a spoilt child". The experience was such that the women were isolated and discarded as wrong elements that were not having positive contribution to society other than spoiling the young girls.

The study thus revealed that women who induced abortions were in hiding and suffered silently well aware that society would only hold them with low esteem. This finding relates and agrees with what researcher like Rees and Sabia (2007); Pedersen (2008) found out that 
there was a correlation between abortion and depression along with other outcomes such as anxiety disorders or substance abuse disorders. Finally, Kersting, Kroker, Steinhard et al. (2009) found out that there was a correlation between abortion and loss of self-esteem alone.

The study revealed that almost all school going women or girls lost their studies owing to inducing abortions. This was partly because they fell sick on and off and partly because their sponsors could not help sponsoring such "spoilt" girls. In one of the revelations, a respondent said,

".... I decided in pain and induced it (abortion) in order to go back to school but, unfortunately, I lost both the baby and studies.”

Another lady confessed,

"I was schooling and my future was lost because of that induced abortion yet my parents had little money ..."

Losing both an abortion and stopping studying was such a regrettable experience gone through by many of the formerly school going girls who induced abortions. These findings seem not to agree with what other researchers found out earlier. For instance, Broen et al., (2005) found that abortion is highly related to important positive life outcomes concerning education, career trajectory, and income level as compared to women who carry unplanned pregnancies to term (Fergusson, Boden \& Horwood, 2007). However, in Rakai, most of the mothers involved found themselves unable to complete the studies.

\subsection{Long-term lived experiences after induced abortion}

Common among the long-term experiences was the difficulty to conceive after an induced abortion. Others failed completely to conceive again, and a lot of disappointment came with such failures. Mothers went through a life of great agony, regret, confusion and selfblaming. The study revealed that mothers had their marriages being threatened due to failure to produce or at least show signs of pregnancy. In one of the interactions, a woman said,

"...I got married and no child at all. I am worried most of the time. I think God had created only those two children in my womb that I aborted!!!"

Another woman confessed,

"Now I got a man and no child for a full year now!! So am confused. I want a baby but in vain.Sometimes I get great pain and I see as if my child is asking me "why did you do this mummy"

The study thus revealed that one of the lived long-term lives was associated with failure to conceive again after an induced abortion. This finding does not agree with Gan, Zou, Wu, Li (2008) who asserted that women should be informed that there are no proven associations between induced abortion and subsequent ectopic pregnancy, placenta praevia or infertility. In Rakai, many of the women blamed their secondary barrenness to their history of induced abortion.

\section{Conclusions}

The study concludes that women experience financial, emotional, psychological, environmental, financial, religious, and circumstantial lives before they actually decide to abort their pregnancies.

The study concludes that the use of local herbs increases the dangers associated with induced abortion. Many of the women go for induced abortion while not prepared financial and emotionally as many do this in hiding, in hurry, in a constrained environment and worst of all under unprofessional guidance. This exacerbates the risks some of which a life threating and others are irreversible.

Health workers and women in child bearing age need to work together to discuss how to control unplanned pregnancies. Mothers should be given pre-natal counseling and School-going children should be educated about contraception.

\section{Acknowledgement}

The authors would wish to acknowledge the technical support of the staff of Faculty of Health Science _ Uganda Martyrs University, in this study. We remain indebted to all our research participants who offered the information.

\section{Conflict of interest}

We declare not conflict of interest, in what-so-ever way.

\section{Funding}

There was no external funding for this study

\section{Consent for publication}

The authors of this manuscript do consent for publication under the journal provided terms and conditions.

\section{References}

[1] Alex, L., \&Hammarström, A. (2004). Women's experiences in connection with induced abortion - a feminist perspective. Scandinavian Journal of Caring Services, 18 (2): 160-168. https://doi.org/10.1111/j.1471-6712.2004.00257.x. 
[2] Allanson, S. (2007). Abortion decision and ambivalence: Insights via an abortion decision balance sheet. Clinical Psychologist, 11(2), 5060.https://doi.org/10.1080/13284200701675767.

[3] Academy of Medical Royal Colleges (AMRC). (2011).Induced Abortion and Mental Health - A Systematic Review of the Mental Health Outcomes of Induced Abortion, Including Their Prevalence and Associated Factors. London: Author.

[4] Andrews, J. \& Boyle, J. (2013). African American Adolescents' Experiences with Unplanned Pregnancy and Elective Abortion. Health Care for Women International, 24 (5): 414-433https://doi.org/10.1080/07399330303995.

[5] Appiah-Agyekum, N N, 2014. Abortions in Ghana: experiences of university students. Health Science Journal, 8 (4). pp. 531-540

[6] Astbury-Ward, E.(2008). Emotional and psychological impact of abortion: a critique of the literature. CFSRH $J$ FamPlannReprod Health Care 2008: 34(3). https://doi.org/10.1783/147118908784734954.

[7] Atuyambe, L., Mirembe, F., Johansson, A., Kirumira, E.K.,\& Faxlid, E. (2005).Experiences of pregnant adolescents-voices from Wakiso distrit, Uganda.African Health Sciences, 2005. pp. 5(4), 304-9.

[8] Bankole, A., Adewole,I, F., Hussain, H., Awolude, O., Singh, S. \&Akinyemi, J. O.(2015).The Incidence of Abortion in Nigeria. International Perspectives on sexual and reproductive health, 41(4): 170 - 181.https://doi.org/10.1363/intsexrephea.41.4.0170.

[9] Barnard, C.(1990). The Long-Term Psychological Effects of Abortion. Institute for Pregnancy Loss. Portsmouth, N.H

[10] Bellieni, C. V. \&Buonocore, G.(2013). Abortion and subsequent mental health: Review of the literature. Psychiatry ClinNeurosci, 67: 301-310. https://doi.org/10.1111/pcn.12067.

[11] Bender, S. S., \&Geirrson, R.T.(2004). Effectiveness of preabortion counseling on postabortion contraceptive use. Contraception, 69(6), 481-487. https://doi.org/10.1016/j.contraception.2003.12.014.

[12] Bennett, L.R.(2001). Single women's experiences of premarital pregnancy and induced abortion in Lombok, Eastern Indonesia. Reproductive Health Matters. 2001, 9 (17): 37-43. https://doi.org/10.1016/S0968-8080(01)90006-0.

[13] Bianchi,D.F.,Perrin,E., Bianchia,P.,Dumont, P.,Lüdicke, F.\&Campana, A. (2003). Contraceptive practice before and after termination of pregnancy: a prospective study. Contraception, 67(2), 107-113. https://doi.org/10.1016/S0010-7824(02)00475-4.

[14] Boemer,M.R.,\&Mariutti,M.G.(2010). A woman's Experiences of Abortion: A qualitative study. Rev Esc Enferm USP.; 37(2):59-71. https://doi.org/10.1590/S0080-62342003000200008.

[15] Bradshaw, Z., \& Slade, P. (2003). The Effects of Included Abortion on Emotional Experiences and Relationships: A Critical Review of the Literature. Clinical Psychology Review, 23(7), 929-958. https://doi.org/10.1016/j.cpr.2003.09.001.

[16] Bradshaw, Z., \& Slade, P. (2005). The relationships between induced abortion, attitudes towards sexuality and sexual problems. Sexual and Relationship Therapy, 20(4), 391-406. https://doi.org/10.1080/14681990500228548.

[17] Bradshaw, Z. \& Slade, P. (2009). The effects of induced abortion on emotional experiences and relationships: A critical review of the literature. Clinical Psychology Review 23(7):929-58. https://doi.org/10.1016/j.cpr.2003.09.001.

[18] Broen, A. N.,Moum, T., Bödtker, A. S., \&Ekeberg, Ö. (2005b). Reasons for induced abortion and their relation to women's emotional distress: A prospective, two-year follow-up study. General Hospital Psychiatry, 27(1), 36-43. https://doi.org/10.1016/j.genhosppsych.2004.09.009.

[19] Brown et al. (1993). Prolonged grieving after abortion; a descriptive study. Journal of Clinical Ethics, 4 (2), $118-23$ p 120

[20] Burke, K. T.(1994). Abortion and Post Traumatic Stress Disorder: The Evidence Keeps Piling Up. . 1994.

[21] Carvalho, G.M., Merighi, M.A.B., Jesus, M.C.P.(2010). The experience of repeated fatherhood during adolescence. Midwifery.2010;26:469.74https://doi.org/10.1016/j.midw.2008.10.007.

[22] Center for Reproductive Rights. (2012). Briefing paper a technical guide to understanding the legal and policy framework on termination of pregnancy in Mainland Tanzania.

[23] Colman, S., \& Joyce, T. (2011). Regulating abortion: impact on patients and providers in Texas. J Policy Anal Manage.2011;4:77597https://doi.org/10.1002/pam.20603.

[24] Cozzarelli, C., Major, B., Karrasch, A., \&Fuegen, K. (2000). Women's experiences of and reactions to antiabortion picketing. Basic and Applied Social Psychology, 22(4), 265-275. https://doi.org/10.1207/S15324834BASP2204_1.

[25] Center for Reproductive Rights (CRR). (2011).10 key points about Uganda's laws and policies on termination of pregnancy. New York : Author

[26] Center for Reproductive Rights (CRR). ( 2012). Abortion and the law in Uganda, Q\&A,. New York: Author

[27] Dennis, A, Henshaw, S.K., Joyce, T.J., Finer, L.B., Blanchard, K.(2009). The impact of laws requiring parental involvement for abortion: a literature review. New York: Guttmacher.

[28] Dias, T.Z., Passini, R., Duarte, G.A., Sousa, M.H., Faúndes, A.(2014). Association between educational level and access to safe abortion in a Brazilian population. Int J Gynecol Obstet.; 128(3):224-7 https://doi.org/10.1016/j.ijgo.2014.09.031.

[29] Dykes K, Slade, P.,\&Haywood, A.(2011).Long term follow-up of emotional experiences after termination of pregnancy: women's views at menopause.Journal of Reproductive and Infant Psychology. 29(1) 2011. https://doi.org/10.1080/02646838.2010.513046.

[30] Elliot Institute (2009). Abortion Risks: A list of major psychological complications related to abortion.

[31] Elul, B., Pearlman, E., Sorhaindo, A., Simonds, W., Westhoff, C.(2000). In-depth Interviews with Medical Abortion Clients: Thoughts on the Method and Home Administration of Misoprostol. J Am Med Womens Assoc. 2000, 55 (3 Suppl): 169-172.

[32] Ertelt, S. (2010). Recent Studies Confirm Women Face Depression After Abortion, Other Problems LifeNews.com Editor. September 28, 2010. Washington, DC (LifeNews.com)

[33] Everett, Koop,C. (1987).The Surgeon General's Report on the Public Health Effects of Abortion. 1987.

[34] Fergusson, D. M., Boden, J. M., \&Horwood, L. J. (2007). Abortion among young women and subsequent life outcomes. Perspectives on Sexual and Reproductive Health, 39(1), 6-12. https://doi.org/10.1363/3900607.

[35] Fergusson, D.M., Horwood, L.J., Boden, J. M. (2009). Reactions to abortion and subsequent mental health. The British Journal of Psychiatry, 195 (5) 420-426.https://doi.org/10.1192/bjp.bp.109.066068.

[36] Fielding, S.L., Edmunds, E., \&Schaff, E.A.(2002). Having an Abortion Using Mifepristone and Home Misoprostol: A Qualitative Analysis of Women's Experiences. Perspectives on Sexual and Reproductive Health. 34 (1): $34-40$. https://doi.org/10.2307/3030230.

[37] Finer, L. B., Frohwirth, L. F., Dauphinee, L. A., Singh, S., \& Moore, A. M. (2005). Reasons U.S. women have abortions: Quantitative and qualitative perspectives. Perspectives on Sexual and Reproductive Health, 37(3), 110-118. https://doi.org/10.1363/3711005.

[38] Finlay, L.(2011). Interpretative Phenomenological Analysis, in Phenomelogy for Therapist: Researching the lived World. Chichester, UK : John Wiley \& Sons

[39] Fuentes, L., Lebenkoff, S., White, K., Gerdts, C., Hopkins, K., Potter, J. E., \& Grossman, D. (2016). Women's experiences seeking abortion care shortly after the closure of clinics due to a restrictive law in Texas.Contraception, 93(4), 292297https://doi.org/10.1016/j.contraception.2015.12.017.

[40] Gan C, Zou Y, Wu S, Li Y, Liu Q (2008). The influence of medical abortion compared with surgical abortion on subsequent pregnancy outcome. Int J GynaecolObstet2008;101:231-8.https://doi.org/10.1016/j.ijgo.2007.12.009.

[41] Geller, P.A., Psaros, C., Kornfield, S.L.(2010).Satisfaction with pregnancy loss aftercare: Are women getting what they want?Arch. WomensMent. Health2010; 13: 111-124.https://doi.org/10.1007/s00737-010-0147-5.

[42] Ghosh, S., Acharya, R., Kalyanwala, S., Jejeebhoy, S. (2008). Understanding client satisfaction: Does quality of care matter? Findings from Maharashtra and Rajasthan. Development Studies, Institute of Development Studies Kolkata, Kolkata, Youth and Adolescent Health, Population Council, New Delhi, India, GHF2008.

[43] Gravensteen, I. K., Helgadóttir, L.B., Jacobsen, E., Rådestad, I., Sandset, P.,\&Ekeberg, O. (2013). Women's experiences in relation to stillbirth and risk factors for long-term post-traumatic stress symptoms: a retrospective study. https://doi.org/10.1136/bmjopen-2013-003323.

[44] Grossman, D., Baum, S., Fuentes, L., White, K., Hopkins, K., Stevenson, A.(2014). Change in abortion services after implementation of a restrictive law in Texas. Contraception. 2014;90:496-501https://doi.org/10.1016/j.contraception.2014.07.006. 
[45] Halldén, B.M., Christensson, K., Olsson, P.(2005).Meanings of Being Pregnant and Having Decided on Abortion: Young Swedish Women's Experiences. Health Care for Women International. 2005, 26 (9): 788-806. https://doi.org/10.1080/07399330500230961.

[46] Harden, A., Ogden, J.(1999). Young women's experiences of arranging and having abortions. Sociology of Health and Illness. 1999, 21 (4): 426444. https://doi.org/10.1111/1467-9566.00165.

[47] Helgeson, V. S., Reynolds, K. A., \&Tomich, P. L. (2006). A meta-analytic review of benefit finding and growth. Journal of Consulting and Clinical Psychology, 74(5), 797-816. https://doi.org/10.1037/0022-006X.74.5.797.

[48] Hemmerling, A, Siedentopf, F., Kentenich, H.(2005). Emotional impact and accessibility of medical abortion with mifepristone: a German experience. J PsychosomObstetGynaecol2005; 26: 23-31.https://doi.org/10.1080/01443610400023056.

[49] Henshaw, S.W.,|\& Kost, K. (2008). Trends in the characteristics of women obtaining abortions. New York,US : Guttmacher,org.

[50] Hessini, L. (2014) . A Learning Agenda for Abortion Stigma: Recommendations from the Bellagio Expert Group Meeting. s.l. : Women Health, 2014. pp. 54 (7), 617-21.https://doi.org/10.1080/03630242.2014.919987.

[51] Johnson, B.,\& Christenssen, L.(2008). Educatuion Research: Quantitative, Qualitative, and mixed Approaches,3rd ED.Thousand Oaks,CA: Sage Publication

[52] Jones, Rachel, K., \& Jerman, Jenna (2014). Abortion Incidence and Service Availability in the United States, 2011." Perspectives on Sexual and Reproductive Health. 2014. p. 46(1).https://doi.org/10.1363/46e 0414.

[53] Joyce, T.J., Henshaw, S.K., Dennis, A., Finer, L.B., Blanchard, K.(2009). The impact of state mandatory counseling and waiting period laws on abortion: a literature review. New York: Guttmacher Institute

[54] Kassebaum, N.J., Bertozzi-Villa, A., Coggeshall, M.S., Shackelford, K.A., Steiner, C., HeutonKR.(2014). Global, regional, and national levels and causes of maternal mortality during 1990-2013: a systematic analysis for the Global Burden of Disease Study 2013. Lancet, 13;384(9947):9801004.

[55] Kate Cockrill, K.,\& Hessini, L. (2014). Introduction: Bringing Abortion Stigma into Focus.Women Health, 2014. pp. 54(7) :5938.https://doi.org/10.1080/03630242.2014.947218.

[56] Keogh, S.C., Kimaro, G., Muganyizi, P., Philbin, J., Kahwa, A., Ngadaya, E. (2015). Incidence of Induced Abortion and Post-Abortion Care in Tanzania. PLOS ONE 10(9)https://doi.org/10.1371/journal.pone.0133933.

[57] Kero, A., Högberg, U., \&Lalos, A.(2004). Wellbeing and mental growth-long-term effects of legal abortion. SocSci Med. 2004, 58 (12): 2559 2569. https://doi.org/10.1016/j.socscimed.2003.09.004.

[58] Kersting, A., Kroker, K., \&Steinhard (2009).Psychological impact on women after second and third trimester termination of pregnancy due to fetal anomalies versus women after preterm birth: A 14-month follow up study. Arch. WomensMent. Health2009; 12: 193201.https://doi.org/10.1007/s00737-009-0063-8.

[59] Khan, S., Bradley, S., Fishel, J., \& Mishra, V.(2008).Unmet Need and Demand for Family Planning in Unganda: Further Analysis of the Uganda Demographic and Health Surveys, 1995-2006. Calverton, Maryland,USA : Macro International Inc.

[60] Kidist, D.(2015). Exploring Women's Socio-Emotional Experiences of Induced Abortion in Marie Stopes Ethiopia. MA Thesis submitted, Addis Ababa University.

[61] Knowles, J.,\&Chesler, E. (2009).Margaret Sanger — 20th Century HeroWashington, DC: 202-973-4848

[62] Kumar, U., Baraitser, P., Morton, S.,\&Massil, H.(2004). Decision making and referral prior to abortion: a qualitative study of women's experiences. Journal of Family Planning and Reproductive Health Care, 30 (1): 51-54. https://doi.org/10.1783/147118904322702009.

[63] Lafaurie, M.M., Grossman, D., Troncoso, E., Billings,D.L., Cháveze, S.(2005). Women's Perspectives on Medical Abortion in Mexico, Colombia, Ecuador and Peru: A Qualitative Study .Reproductive Health Matters. 2005, 13 (26): 75-83. https://doi.org/10.1016/S0968-8080(05)26199-2.

[64] Larsson, S., Eliasson, M., KlingbergAllvin, M., Faxelid, E., Atuyambe, L., Fritzell, S.(2015). The discourses on induced abortion in Ugandan daily newspapers: a discourse analysis. Reproductive Health; 12:58. https://doi.org/10.1186/s12978-015-0049-0.

[65] Lee, E., Clements, S., Ingham, R., \& Stone, N.(2004). A matter of choice? Explaining national variations in teenage abortion and motherhood. New York: Joseph Rowntree Foundation

[66] Lema, V.M.(2005). Maternal mortality at the Queen Elizabeth Central Teaching Hospital, Blantyre, Malawi, East African Medical Journal, 2005, 82(1):3-9.https://doi.org/10.4314/eamj.v82i1.9286.

[67] Levandowski, B.A., Mhango, C., Kuchingal, E., Lunguzi, J.,Katengeza, H., Gebreselassie,H., \&Singh, S. (2013). The Incidence of Induced Abortion in Malawi. International Perspectives on Sexual and Reproductive Health, 39(2),Pages 88 - 96 https://doi.org/10.1363/3908813.

[68] Lie, M. L., Robson, S.C. \& May, C.R.(2008). Experiences of abortion: A narrative review of qualitative studies. BMC Health Services Research,20088:150. https://doi.org/10.1186/1472-6963-8-150.

[69] Lunneborg, P. W. (1992). Abortion: A Positive Decision. New York: Bergin \& Garvey.

[70] Maina., B.W., Mutua, M.M.,\&Sidze, E. M (2015). Factors associated with repeat induced abortion in Kenya. BMC Public Health,201515:1048. https://doi.org/10.1186/s12889-015-2400-3.

[71] Major, B. ,\&Gramzow, R. H. (1999). Abortion as stigma: Cognitive and emotional implications of concealment. Journal of Personality and Social Psychology, 77(4), 735-745. https://doi.org/10.1037/0022-3514.77.4.735.

[72] Major, B., Appelbaum, M., Beckman, L., Dutton, M. A., Russo, N. F., \& West, C. (2009). Abortion and mental health: Evaluating the evidence. American Psychologist, 64(9), 863-890. https://doi.org/10.1037/a0017497.

[73] Major, B., \&Cozzarelli, C. (1992). Psychosocial predictors of adjustment to abortion. Journal of Social Issues, 48(3), 121-142. https://doi.org/10.1111/j.1540-4560.1992.tb00900.x.

[74] Major, B., Cozzarelli, C., Cooper, M. L., Zubek, J., Richards, C., Wilhite, M., \&Gramzow, R. H. (2000). Psychological responses of women after first-trimester abortion. Archives of General Psychiatry, 57(8), 777-784. https://doi.org/10.1001/archpsyc.57.8.777.

[75] Major, B., Cozzarelli, C., Sciacchitano, A. M., Cooper, M. L., Testa, M., \& Mueller, P. M. (1990). Perceived social support, self-efficacy, and adjustment to abortion. Journal of Personality and Social Psychology, 59(3), 452-463. https://doi.org/10.1037/0022-3514.59.3.452.

[76] Major, B., Richards, C., Cooper, M. L., Cozzarelli, C., \&Zubek, J. (1998). Personal resilience, cognitive appraisals, and coping: An integrative model of adjustment to abortion. Journal of Personality and Social Psychology, 74(3), 735-752. https://doi.org/10.1037/0022-3514.74.3.735.

[77] Major, B., Zubek, J. M., Cooper, M. L., Cozzarelli, C., \& Richards, C. (1997). Mixed messages: Implications of social conflict and social support within close relationships for adjustment to a stressful life event. Journal of Personality and Social Psychology, 72(6), 1349-1363. https://doi.org/10.1037/0022-3514.72.6.1349.

[78] Major, B.,\& Gramzow, R.H. (1999). Abortion as stigma: Cognitive and emotional implications of concealment. s.l. J Pers Soc Psychol, 1999. pp. 77(4), 735-45.https://doi.org/10.1037/0022-3514.77.4.735.

[79] Major, B. \& O'Brien, L.T.(2005).The social psychology of stigma. s.l.: Annu Rev Psychol, 2005. pp. 56: 393421.https://doi.org/10.1146/annurev.psych.56.091103.070137.

[80] Mann, J. R., McKeown, R.E., Bacon, J., Vesselinov, R., Bush, F.(2008).Predicting depressive symptoms and grief after pregnancy loss. J. Psychosom. Obstet. Gynaecol.2008; 29: 274-279.https://doi.org/10.1080/01674820802015366.

[81] Margaret Sanger (1879-1966).Woman and the New Race, Women's Struggle for Freedom, 1920.

[82] Mariutti, M.G., Furegato, A.R.F. (2010). Factors affecting rates of depression among women who have undergone induced abortion. Rev Bras Enferm, 63(2):183-9. https://doi.org/10.1590/S0034-71672010000200003.

[83] McIntyre, M., Anderson, B., McDonald, C.(2001). The Intersection of Relational and Cultural Narratives: Women's Abortion Experiences. Canadian Journal of Nursing Research, 33(3): 47-62.

[84] Melo, F.R.M., Lima, M.S., Alencar, C.H. Jr, ANR, Costa, F.H., Machado, M.M.T, Heukelbach, J. (2014).Temporal trends and spatial distribution of unsafe abortion in Brazil.RevSaúdePública. 1996-2012. 
[85] Mohamed ,S.F., Izugbara, C, Moore, A.M (2015). The estimated incidence of induced abortion in Kenya: a cross-sectional study. BMC Pregnancy and Childbirth. 2015;15:185. https://doi.org/10.1186/s12884-015-0621-1.

[86] Munk-Olsen, T.,Laursen, T.M.,Pedersen, C.B., Lidegaard, Ø., Mortensen, P.B.(2011). Induced first-trimester abortion and risk of mental disorder. N. Engl. J. Med.2011; 364: 332-339.https://doi.org/10.1056/NEJMoa0905882.

[87] Nader, P.R.A, Blandino, VRP.,Maciel, ELN. (2007). Characterístics of abortion among women attneing maternity public helathcentres in Serra ES. Rev Bras Epidemiol [Internet] 2007 10(4):615-24. Disponívelem: http://www.scielo.br/pdf/rbepid/v10n4/18.pdf .https://doi.org/10.1590/S1415-790X2007000400019.

[88] Nalwadda, G, Nabukere, S.,\& Salihu, H.M. (2005). Theabortion paradox in Uganda: fertility regulator or cause of maternal mortality.s.1. : J Obstet Gynaecol, 2005. pp. 25(8): 776-80.https://doi.org/10.1080/01443610500328074.

[89] Nalwadda, G., Mirembe, F., Tumwesigye, N.M., Byamugisha, J., \& Faxelid, E. (2011).Constraints and prospects for contraceptive service provision to young people in Uganda: provider's perspectives. s.1. BMC Health Serv Res, 2011. p. 11:220.https://doi.org/10.1186/1472-6963-11$\underline{220}$.

[90] Ndunyu, L.N.(2013). Women's Experiences of Induced Abortion in Mombasa City and the Kilifi District, Kenya. PhD Thesis, University of KwaZulu-Natal, 2013

[91] Norris, A., Harrington, B. J., Grossman, D., Hemed, M., \&Hindin, M. J. (2016). Abortion experiences among Zanzibari women: a chain-referral sampling study. Reproductive Health, 13, 23. https://doi.org/10.1186/s12978-016-0129-9.

[92] Pedersen, W.(2008).Abortion and depression: A population-based longitudinal study of young women. Scand. J. Public Health2008; 36: 424428.https://doi.org/10.1177/1403494807088449.

[93] Polis, C., Wawer, M.J., Serwadda, D., Nalugoda, F., Kiwanuka, N., Kagaayi, J., Chen, M., Brahmbhatt, H., Gray, R.H.(2009). Effect of Hormonal Contraceptives Use on Time to AIDS or Death in Female HIV Sero-converters in Rakai, Uganda. 16 ${ }^{\text {th }}$ Conference on Retroviruses and Opportunistic Infections, Montreal, Canada. February 8-11, (Poster).

[94] Prada, E., Mirembe, F., Ahmed, F.H., Nalwadda, R.,\& Kiggundu, C.(2005).Abortion and postabortion care in Uganda:a report from health care proffessionals and health facilities. New York : The Alan Guttmacher Institute, 2005.

[95] Rakai Health Sciences Program (RHSP), 2010. STATUS REPORT 2010 (2010)

[96] Rasch ,V., Sørensen, P.H., Wang, A.R., Tibazarwa, F.,Jäger, A.K.(2014). Unsafe abortion in rural Tanzania - the use of traditional medicine from a patient and a provider perspective. BMC Pregnancy Childbirth. 2014;14(1):419. https://doi.org/10.1186/s12884-014-0419-6.

[97] Rasch, V. (2011).Unsafe abortion and postabortion care-an overview. s.1. : Acta Obstet Gynecol Scand, 2011.https://doi.org/10.1111/j.16000412.2011.01165.x.

[98] Reardon, D.C., \& Coleman, P.K. (2006). Relative Treatment Rates for Sleep Disorders and Sleep Disturbances Following Abortion and Childbirth: A Prospective Record Based-Study, Sleep 29(1):105-106, 2006.https://doi.org/10.1093/sleep/29.1.105.

[99] Reardon, D.C., Cougle, J.R., Rue, V.M., Shuping, M.W., Coleman, P.K., Ney, P.G.(2003)Psychiatric admissions of low-income women following abortion and childbirth. CMAJ2003; 168: 1253-1256.

[100] Rees, D.I.,\&Sabia, J.J. (2007).The relationship between abortion and depression: New evidence from the fragile families and child wellbeing study. Med. Sci. Monit.2007; 13: CR430-CR436.https://doi.org/10.12659/MSM.502357.

[101] Rehnström, L.U, Gemzell-Danielsson, K, Faxelid, E, Klingberg-Allvin, M. (2015). Health care providers' perceptions of and attitudes towards induced abortions in sub-Saharan Africa and Southeast Asia: a systematic literature review of qualitative and quantitative data. BMC Public Health; 15:139. https://doi.org/10.1186/s12889-015-1502-2.

[102] Reminnick, L., \& Segal, R. (2001). Socio-cultural context and women's experiences of abortion: Israeli women and Russian immigrants compared. Culture, Health and Sexuality, 3(1): 49-66. https://doi.org/10.1080/136910501750035671.

[103] Richards,L.(2005). Handling Qualitative Data.

[104] Ringheim,K.(1999).Ethical issues in postabortion care research involving vulnerable sublects. In: Huntington D, Piet-Pelon NJ,editors. Postabortion Care: Lessons from Operations Research. New York : The Population, 1999. pp. 178-976.

[105] Roberts, H., Silva, M., \&Xu, S.(2010). Post abortion contraception and its effect on repeat abortions in Auckland, New Zealand. Contraception; 82 (3):260-5.https://doi.org/10.1016/j.contraception.2010.03.003.

[106] Rocca, C.H., Kimport, K., Roberts, S.C.M., Gould, H., Neuhaus, J., Foster, D.G. (2015). Decision Rightness and Emotional Responses to Abortion in the United States: A Longitudinal Study. Dekel S, ed. PLoS ONE. 2015;10(7):e0128832. https://doi.org/10.1371/journal.pone.0128832.

[107] Russo, N. F.(2008). Understanding emotional responses after abortion. In J. C. Chrisler, C., Golden \&Rozee, P. D. (Eds.), (pp. 173-189). New York, NY, US: McGraw-Hill.

[108] Say, L., Chou, D., Gemmill, A., Tuncalp, O., Moller, A.B., Daniels, J.(2014).Global causes of maternal death: a WHO systematic analysis. Lancet Glob Health 2014 Jun;2(6):e323-e333. https://doi.org/10.1016/S2214-109X(14)70227-X.

[109] Schutz, A. (1967). The phenomenology of the social world. Evanston, IL: Northwestern University Press

[110] Sedgh, G. (2010). Abortion in Ghana. Issues in brief. New York: Alan Guttmacher Institute)

[111] Sedgh, G, Rossier, C., Kabore, I., Bankole, A., Mikulich, M.(2007). Induced abortion: estimated rates and trends worldwide. Lancet; 370(9595):1338-45. https://doi.org/10.1016/S0140-6736(07)61575-X.

[112] Sell, S.E., Kotzias, E.A., Velho, B.M., Erdmann, A.L., Rodriguez, M.H. (2015). Reasons and meanings attributed by women who experienced induced abortion: an integrative review. Rev. esc. enferm. 49(3). https://doi.org/10.1590/S0080-623420150000300019.

[113] Shah, I. \& Ahman,E.(2009).Unsafe abortion: Global and regional Incidence, Trends,Consequences, and Challenges. s.l. : J Obstet Gynaecol Can, 2009. pp. 31(12),1149-58.https://doi.org/10.1016/S1701-2163(16)34376-6.

[114] Shellenberg, K.M, Hessini, L. \& Levandowski, B.A.(2014). Developing a scale to measure Stigmatizing Attitudes and Beliefs About Women Who Have Abortions:Results from Ghana and Zambia.s.1.: Women Health, 2014. pp. 54(7), 599616.https://doi.org/10.1080/03630242.2014.919982.

[115] Silva, R. S. and Vieira, E.M.(2009). Frequency and characteristics of induced abortion among married and singles women in São Paulo, Brazil. Cad SaúdePública, 25(1):179-87. https://doi.org/10.1590/S0102-311X2009000100019.

[116] Simonds, W., Ellertson, C., Springer, K., Winikoff, B.(1998). Abortion, revised: participants in the U.S. clinical trials evaluate mifepristone. Social Science and Medicine. 1998, 46 (10): 1313-1323. https://doi.org/10.1016/S0277-9536(97)10063-6.

[117] Singh, S, Sedgh, G.,\&Hussain, R.(2010).Unintended Pregnancy: Worlwide Levels, Trends, and Outcomes. s.1. : Stud Fam Plann, 2010. pp. 41(4), 241-50.https://doi.org/10.1111/j.1728-4465.2010.00250.x.

[118] Singh, S. (2006). Hospital admissions resulting from unsafe abortion: estimates from 13 developing countries. Lancet, 25;368(9550):1887-92. https://doi.org/10.1016/S0140-6736(06)69778-X.

[119] Singh, S., GuttmacherInstitute;Prada, E.,Mirembe, F., \&Kiggundu, C. 2005. The Incidence of Induced Abortion in Uganda. International perspective on sexual and reproductive health, 31(4): 183 - 191https://doi.org/10.1363/3118305.

[120] Singh, S., Prada, E., Mirembe, F. \& Kiggundu, C. (2005). The incidence of induced abortion in Uganda. s.1. : Int Fam Plan Perspective, 2005. pp. 31(4), 183-191.https://doi.org/10.1363/3118305.

[121] Singh, S., Wulf, D., Hussain, R., Bankole, A. \& Sedgh, G.(2009).Abortion Worldwide: A Decade of Uneven Progress. New York : Guttmacher Institute, 2009

[122] Smith, J. A., Flowers, P. \& Larkin, M.(2009).Interpretative Phenomenological analysis: Theory, Method, and Research. Los Angeles, CA : Sage Publication

[123] Souza, Z. C. S.\&Diniz, N. M. F. (2011). Abortion factors: A discussion of women's experiences with their families. TextoContexto-Enferm; 20(4):742-750. Disponívelem: http://www.scielo.br/pdf/tce/v20n4/13.pdf. https://doi.org/10.1590/S0104-07072011000400013. 
[124] Steinberg, J. R., \& Finer, L. B. (2011). Examining the association of abortion history and current mental health: A re-analysis of the National Co-morbidity Survey using a common-risk-factors model. Social Science \& Medicine, 72(1), 72-82. https://doi.org/10.1016/j.socscimed.2010.10.006.

[125] Steinberg, J. R., \& Russo, N. F. (2008). Abortion and anxiety: What's the relationship? Social Science \& Medicine, 67(2), $238-252$. https://doi.org/10.1016/j.socscimed.2008.03.033.

[126] Steinberg, J.R.( 2011). Later abortions and mental health.Psychological experiences of women having later abortions-Acritical review research.s.1. : Women's Health Issues, 2011. pp. 21(3), S44-S48.https://doi.org/10.1016/j.whi.2011.02.002.

[127] Stotland, N.(2001). Psychiatric aspects of induced abortion. Arch Womens Mental Health 2001; 4: 2731https://doi.org/10.1007/s007370170005.

[128] Thapa, S., \&Neupane, S. (2013). Risk factors for repeat abortion in Nepal. Int J GynecolObstet; 120(1):326.https://doi.org/10.1016/j.ijgo.2012.07.016.

[129] The Royal College of Psychiatrists (2008). Position Statement on Women's Mental Health in Relation to Induced Abortion, 14 March 2008.

[130] Ting, T.W., Low, W.Y., Wong, Y.T., Choong, S.P.\&Jegasothy, R. (2012). Exploring pregnancy termination experiences and needs among Malaysian women: A qualitative study. BMC Public Health, 12:743. https://doi.org/10.1186/1471-2458-12-743.

[131] Törnbom, M., \&Möller, A.(1999). Repeat abortion: a qualitative study. Journal of Psychosomatic Obstetrics and Gynecology, 20 (1): 21-30. https://doi.org/10.3109/01674829909075573.

[132] Uganda Bureau of Statistics (UBOS)\& ICF International.(2012).Uganda Demographic and Health Survey 2011. Kampala-Uganda, Calverton,MD,USA: Authors

[133] Upadhyay, U.D., Brown, B.A.,Sokoloff, A. \&Raine, T.R.(2012).Contraceptive discontinuation and repeat unintended pregnancy within 1 year after an abortion. Contraception;85(1):56-62.https://doi.org/10.1016/j.contraception.2011.05.009.

[134] Vilma,E.(2006). The meaning of abortion experience for women. Blekinge Institute of Technology.

[135] Warren, J.T., Harvey, S.M., Henderson, J.T.(2010).Do depression and low self-esteem follow abortion among adolescents? Evidence from a national study. Perspect. Sex. Reprod. Health2010; 42: 230-235.https://doi.org/10.1363/4223010.

[136] Welter, L. B. (2015).Mexican-American women and abortion: experiences and reflections. PhD (Doctor of Philosophy) thesis, University of Iowa, 2015.

[137] Worell, J.(2001). Encyclopedia of Women and Gender. Sex similarities and differences and the impact of society on gender. San Diego : Academic Press

[138] World Health Organization (WHO). (2012). Trends in Maternal Mortality :1990 to 2010. Geneva : Author

[139] World Health Organisation (WHO). (2011). Unsafe Abortion: Global and Regional Estimates of the Incidence of Unsafe Abortion and Associated Mortality in 2008, $6^{\text {th }}$ ed. Geneva: Author. 